\title{
Hubungan Antara Karakteristik Klien LSL dengan Hasil Skrining HIV di UPT Puskesmas X Kota Bandung
}

\author{
Suzy Eka Hazairina ${ }^{1}$, Elsa Pudji Setiawati², Indah Amelia ${ }^{2}$ \\ ${ }^{1}$ UPT Puskesmas Ibrahim Adjie Kota Bandung \\ ${ }^{2}$ Departemen Ilmu Kesehatan Masyarakat, Fakultas Kedokteran Universitas Padjadjaran
}

\begin{abstract}
Abstrak
LSL adalah laki-laki yang berhubungan seksual dengan laki-laki. Prevalensi HIV pada LSL tertinggi dilaporkan terjadi di Surabaya sebesar 22,1\%, Bandung 21,3\%, dan Jakarta 19,6\%. Jumlah kunjungan klien poli IMS di UPT Puskesmas X dari bulan Januari sampai bulan Oktober 2016 sebanyak 703 orang, 77,81\% (547 orang) diantaranya adalah klien LSL. Sebanyak 691 orang melakukan skrining HIV, 538 diantaranya adalah klien LSL dengan hasil HIV positif 99 orang. Tujuan penelitian ini adalah untuk mengetahui hubungan antara karakteristik klien LSL dengan hasil skrining HIV di UPT Puskesmas X. Penelitian ini merupakan penelitian analitik, cross sectional, nonprobability purposive sample. Periode penelitian Januari 2017 sampai Februari 2017. Data dianalisis berdasarkan distribusi karakteristik dan chi-square. Hasil penelitian dari 235 subjek, sebanyak 62 orang menunjukkan hasil skrining HIV positif dan didapatkan hubungan antara pendidikan terakhir $(\mathrm{p}=0,003)$, riwayat IMS $(p=0,000)$, peran dalam hubungan seks $(p=0,000)$, dan penggunaan kondom $(p=0,000)$ dengan hasil skrining HIV. Hasil analisis ini merujuk pada hal-hal terkait resiko penularan HIV pada klien LSL di UPT Puskesmas X.
\end{abstract}

Kata kunci : HIV, Karakteristik, LSL, Skrining.

\section{The Relationship Between the Characteristics of MSM Clients with HIV Screening Result in Upt Puskesmas X Bandung City}

\begin{abstract}
MSM are men who have sex with men. The highest rate of HIV were reported in Surabaya at 22.1\%, Bandung at $21.3 \%$, and Jakarta at 19.6\%. The number of client visits OPD STI from January to October 2016 in UPT Puskesmas $X$ as many as 703 people, $77.81 \%$ (547 people) of them are MSM client. A total of 691 people have been screened for HIV, 538 of whom are clients of MSM and HIV positive on the client MSM is 99 people. The relationship between the characteristics of MSM clients who visited OPD in UPT Puskesmas X with $H I V$ screening results still unknown. This research is an analytic research, cross sectional, purposive sample nonprobability. The period of research conducted from January 2017 to February 2017. Data are analyzed based on the characteristics and chi-square. From 235 people of total subject, were obtained 62 people with HIV positive screening result and the results of the analysis of the characteristics of clients MSM who screen HIV obtained their relationship to the characteristics of the last education $(p=0.003)$, history of STIs $(p=0.000)$, the role of sex with men $(p=0.000)$, and condom use $(p=0.000)$ client MSM with HIV screening results. This analization refers to matters related to the risk of contracting HIV positive MSM clients in UPT Puskesmas X.
\end{abstract}

Keywords : Characteristic, HIV, MSM, Screening.

\footnotetext{
Korespondensi:

Suzy Eka Hazairina, dr

UPT Puskesmas Ibrahim Adjie Kota Bandung

Jl. Ibrahim Adjie No.88, Kota Bandung

Mobile : 082130130187

Email : hzsuzyeka@gmail.com
} 


\section{Pendahuluan}

Dunia telah berkomitmen untuk menuntaskan epidemi AIDS pada tahun 2030. HIV-AIDS di Indonesia pertama kali ditemukan tahun 1987 dan sampai dengan Desember 2014, telah menyebar ke 407 (80\%) dari 507 kabupaten/ kota di seluruh provinsi di Indonesia. Temuan kasus HIV dan AIDS di Provinsi Jawa Barat sejak tahun 1989 sampai Desember 2015 telah mencapai 20.296 kasus HIV positif dan 6.222 kasus AIDS. Temuan ini menempatkan Jawa Barat sebagai peringkat ke-4 terbesar kasus HIV positif di Indonesia setelah DKI Jakarta, Jawa Timur, dan Papua, sementara untuk kasus AIDS Jawa Barat menempati peringkat ke-6 setelah Jawa Timur, Papua, DKI Jakarta, Bali dan Jawa Tengah. Pada tahun 1987 sampai tahun 1997, penularan dominan pada kelompok homoseksual, tahun 1997 - 2007 penularan dominan ditemukan pada kelompok pengguna jarum suntik narkoba dan tahun 2007 hingga sekarang penularan lebih banyak ditemukan pada kelompok heteroseksual. ${ }^{1}$ Walaupun demikian, penularan melalui kelompok homoseksual tetap tinggi.

Hasil pemetaan yang telah dilakukan pada tahun 2011, kelompok berisiko HIV/AIDS di Kota Bandung sebanyak 9.823 orang, yang terdiri dari WPS (1.037), laki-laki berisiko tinggi (4.035), penasun (1.751), LSL (2.725) dan waria (275).2 Menurut data tersebut, jumlah LSL menempati urutan kedua kelompok berisiko HIV AIDS di Bandung melebihi penasun.

LSL adalah laki-laki yang berhubungan seksual dengan laki-laki, atau disebut juga dengan gay. Saat ini, LSL tidak termasuk gangguan kejiwaan yang timbul dari pola asuh orang tua dalam keluarga, namun lebih kepada faktor lingkungan yang mendorong seseorang untuk berperilaku demikian. ${ }^{3}$ Khusus pada populasi LSL atau gay, prevalensi HIV cukup tinggi di wilayah urban perkotaan di Indonesia. Prevalensi HIV pada LSL tertinggi dilaporkan terjadi di Surabaya sebesar 22,1\%, Bandung 21,3\%, dan Jakarta 19,6\%. Menurut UNAIDS Indonesia, cakupan penjangkauan program pencegahan HIV pada populasi LSL masih sangat rendah. Untuk itu, dibutuhkan inovasi program untuk mendekatkan komunitas pada layanan, seperti promosi dengan penggunaan sosial media, atau skrining HIV berbasis komunitas. ${ }^{4}$

Komunitas LSL merupakan hidden population pada penularan kasus HIV-AIDS. Kelompok ini terbagi menjadi dua, yaitu laki-laki yang hanya melakukan hubungan seks dengan laki-laki atau MSMO (Men Have Sex with Men Only) dan laki-laki yang selain berhubungan dengan laki-laki, juga berhubungan dengan wanita atau MSMW (Men Sex with Men and Women). ${ }^{5}$ Perilaku seksual pada LSL ini cenderung bebas, berganti-ganti pasangan, dan tidak menggunakan kondom sehingga meningkatkan risiko kesehatan tertentu, terutama infeksi menular seksual (IMS). Infeksi human immunodeficiency virus (HIV) dan virus herpes simpleks (VHS) termasuk IMS dan dapat berinteraksi secara sinergistik. Pada individu dengan HIV dan koinfeksi VHS dapat terjadi peningkatan risiko transmisi HIV serta mempercepat perburukan ke arah AIDS. ${ }^{6}$

UPT Puskesmas X, merupakan salah satu fasilitas kesehatan primer di Kota Bandung yang melaksanakan skrining HIV melalui pemeriksaan PITC (Provider Inisiation Test Counselling) dan VCT (Voluntary Counselling Test) terintegrasi pada layanan KIA, IMS (Infeksi Menular Seksual) di Poli Someah. VCT merupakan upaya pencegahan dan pintu masuk ke layanan manajemen kasus serta perawatan, dukungan, dan pengobatan bagi penderita HIV-AIDS. ${ }^{7}$ Jumlah kunjungan klien LSL yang datang ke Poli Someah saat ini semakin meningkat, baik untuk memeriksakan IMS maupun untuk melakukan skrining HIV. Jumlah kunjungan klien poli IMS di UPT Puskesmas X dari bulan Januari sampai bulan Oktober 2016 sebanyak 703 orang, 77,81\% (547 orang) diantaranya adalah klien LSL. Dari jumlah pengunjung 691 orang melakukan skrining HIV, 538 orang diantaranya merupakan klien LSL dan hasil HIV positif pada klien LSL adalah 99 orang.

Meningkatnya kunjungan klien LSL yang melakukan skrining HIV dan hasil skrining HIV positif yang cukup besar pada klien LSL menjadi fokus utama penulis untuk melakukan penelitian, mengingat HIV mudah menular melalui perilaku seks berisiko. Berdasarkan keterangan tersebut, penulis bermaksud melakukan penelitian untuk mengetahui hubungan antara karakteristik klien LSL yang berkunjung ke poli IMS Someah di UPT Puskesmas X dengan hasil skrining HIV. Harapan penulis dengan mengetahui karakteristik klien LSL akan memudahkan perencanaan intervensi kegiatan penanggulangan HIV AIDS melalui kegiatan promotif dan preventif.

\section{Metode}

Penelitian ini merupakan penelitian deskiptif analitik dengan rancangan potong lintang (cross sectional). Kriteria inklusi pada penelitian ini adalah klien LSL yang melakukan skrining HIV di UPT Puskesmas X. Sedangkan kriteria eksklusinya adalah klien selain LSL seperti waria, penasun, pasangan risti, dan kelompok berisiko lainnya, serta klien LSL yang telah mengisi 
kuesioner penelitian yang sama sebelumnya. Klien LSL HIV diketahui dari informasi LSM (Lembaga Swadaya Masyarakat) yang melakukan penjangkauan dan pendampingan pada komunitas LSL tersebut, juga dari pengisian formulir tes dan konseling HIV yang telah dilakukan sebelumnya, serta hasil skrining HIV yang dilakukan di Laboratorium UPT Puskesmas X.

Pengumpulan data dilakukan pada bulan Januari 2017 sampai dengan bulan Februari 2017. Jumlah sampel minimal didapatkan dengan rumus Slovin sebanyak 227 orang. Teknik sampling yang digunakan yaitu nonprobability purposive sample. Pengambilan data kuesioner klien HIV positif dilakukan oleh LSM, mengingat kerahasiaan dan privasi klien LSL harus tetap dijaga. Pengambilan data kuesioner klien HIV negatif dilakukan oleh peneliti dan konselor setelah klien melakukan skrining HIV dan diketahui hasilnya negatif. Mengingat jumlah sampel yang cukup besar, sebagian data klien HIV negatif didapatkan dari formulir tes dan konseling HIV klien yang melakukan skrining HIV pada bulan Desember 2016 dan bulan Januari 2017 yang belum pernah mengisi kuesioner penelitian ini sebelumnya. Untuk pertanyaan yang belum terjawab ditanyakan oleh LSM melalui telepon. Data yang telah terkumpul dari para responden klien LSL di UPT Puskesmas X dianalisis dengan menggunakan analisis chi-square, dan disajikan dalam bentuk narasi dan tabel.

Tabel akan ditampilkan sesuai dengan karakteristik yang ada pada kuesioner untuk klien LSL. Karakteristik meliputi karakteristik sosiodemografi, seksual, dan klinis. Karakteristik sosiodemografi menggambarkan umur, pekerjaan, pendidikan, domisili dan status pernikahan responden. Karakteristik seksual menggambarkan usia pertama kali melakukan hubungan seksual, jenis kelamin pasangan seksual, kesetiaan terhadap pasangan seks, peran dalam hubungan seksual, penggunaan kondom dan komersialisasi seks responden. Karakteristik klinis menggambarkan riwayat IMS responden. Penelitian ini telah mendapat ethical clearance dari Komite Etik FK Unpad dan telah memenuhi 4 aspek etik, yaitu respect for person, beneficence, maleficence dan justice.

\section{Hasil}

Pada penelitian ini terkumpul responden sebanyak 235 orang. Berikut ini adalah gambaran karakteristik sosiodemografi klien LSL di UPT Puskesmas X, disajikan pada Tabel 1. Pada data umur pertama kali melakukan hubungan seks, dilakukan pengolah data tersendiri untuk mencari mean, median, nilai minimum dan maksimum serta standar deviasi. Usia paling muda melakukan hubungan seks pertama kali adalah 11 tahun, sedangkan usia paling tua melakukan hubungan seks pertama kali adalah 35 tahun. Dari data tersebut, diperoleh nilai rata-rata sebesar 21,1, dengan nilai median 20 dan standar deviasi sebesar 3,336.

Pada tabel 2 Karakteristik klinis diperoleh hanya berdasarkan gejala yang pernah dialami oleh klien LSL, tanpa melakukan pemeriksaan, kecuali klien mempunyai keluhan dan gejala yang bersifat akut atau hasil pemeriksaan sifilis yang dilakukan rutin bersamaan dengan skrining HIV.

Tabel 1 Karakteristik Sosiodemografi Klien LSL di UPT Puskesmas X

\begin{tabular}{lccccc}
\hline Karakteristik & Kategori & HIV + $(\mathbf{n = 6 2})$ & Persentase (\%) & HIV - (n=173) & Persentase (\%) \\
\hline Umur & $15-19$ tahun & 5 & $2,13 \%$ & 15 & $6,38 \%$ \\
& $20-24$ tahun & 25 & $10,64 \%$ & 57 & $24,26 \%$ \\
& $25-49$ tahun & 31 & $13,19 \%$ & 98 & $41,70 \%$ \\
& Lebih dari 50 tahun & 1 & $0,43 \%$ & 3 & $1,28 \%$ \\
Pekerjaan & & & & 8 \\
& PNS/TNI/Polri & 1 & $0,43 \%$ & 76 & $3,40 \%$ \\
& Pegawai Swasta & 34 & $14,47 \%$ & 23 & $9,79 \%$ \\
& Pelajar/Mahasiswa & 11 & $4,68 \%$ & 45 & $19,15 \%$ \\
Lain-Lain & 13 & $5,53 \%$ & 21 & $8,94 \%$ \\
\hline
\end{tabular}


Suzy Eka Hazairina, dr : Hubungan Antara Karakteristik Klien LSL dengan Hasil Skrining HIV di UPT Puskesmas X Kota Bandung

\begin{tabular}{lccccc}
\hline Pendidikan & SD/Setara & 0 & $0 \%$ & 7 & $2,98 \%$ \\
& SMP/Setara & 2 & $0,85 \%$ & 25 & $10,64 \%$ \\
& SMA/Setara & 50 & $21,28 \%$ & 96 & $40,85 \%$ \\
& Akademi/PT & 10 & $4,26 \%$ & 45 & $19,15 \%$ \\
Domisili & & & & $5,11 \%$ \\
& Dalam wilayah kerja & 6 & $2,55 \%$ & 12 & $48,09 \%$ \\
& Luar wilayah kerja & 42 & $17,87 \%$ & 113 & $20,43 \%$ \\
Status & Luar Kota Bandung & 14 & $5,96 \%$ & 48 & $62,55 \%$ \\
Pernikahan & & & & 147 & $7,23 \%$ \\
& Belum Menikah & 57 & $24,26 \%$ & 17 & $3,83 \%$ \\
\hline
\end{tabular}

Tabel 2 Karakteristik Seksual Klien LSL di UPT Puskesmas X

\begin{tabular}{|c|c|c|c|c|c|}
\hline Karakteristik & Kategori & HIV $+(n=62)$ & Persentase (\%) & HIV - $(n=173)$ & Persentase (\%) \\
\hline \multirow{2}{*}{$\begin{array}{l}\text { Jenis Kelamin } \\
\text { Pasangan Seks } \\
\text { Pertama Kali }\end{array}$} & Laki-Laki & 59 & $25.11 \%$ & 107 & $45.53 \%$ \\
\hline & Perempuan & 3 & $1.28 \%$ & 66 & $28.09 \%$ \\
\hline \multirow{2}{*}{$\begin{array}{l}\text { Jenis Kelamin } \\
\text { Pasangan Seks } \\
\text { Sekarang }\end{array}$} & Murni LSL & 57 & $24.26 \%$ & 113 & $48.09 \%$ \\
\hline & Biseksual & 5 & $2.13 \%$ & 60 & $25.53 \%$ \\
\hline \multirow{2}{*}{$\begin{array}{l}\text { Jumlah } \\
\text { Pasangan Seks }\end{array}$} & Satu/Tetap & 17 & $7.23 \%$ & 68 & $28.94 \%$ \\
\hline & Multipartner & 45 & $19.15 \%$ & 105 & $44.68 \%$ \\
\hline \multirow{5}{*}{$\begin{array}{l}\text { Peran } \\
\text { Hubungan } \\
\text { Seks dengan } \\
\text { Laki-Laki }\end{array}$} & Hanya Top & 3 & $1.28 \%$ & 73 & $31.06 \%$ \\
\hline & Kebanyakan Top & 8 & $3.40 \%$ & 19 & $8.09 \%$ \\
\hline & $\begin{array}{c}\text { Top dan Bottom } \\
\text { Berimbang }\end{array}$ & 7 & $2.98 \%$ & 46 & $19.57 \%$ \\
\hline & $\begin{array}{c}\text { Kebanyakan } \\
\text { Bottom }\end{array}$ & 33 & $14.04 \%$ & 13 & $5.53 \%$ \\
\hline & Hanya Bottom & 11 & $4.68 \%$ & 22 & $9.36 \%$ \\
\hline \multirow{5}{*}{$\begin{array}{l}\text { Pemakaian } \\
\text { Kondom }\end{array}$} & Selalu & 0 & $0.00 \%$ & 40 & $17.02 \%$ \\
\hline & Sering & 1 & $0.43 \%$ & 25 & $10.64 \%$ \\
\hline & Kadang-kadang & 23 & $9.79 \%$ & 56 & $23.83 \%$ \\
\hline & Jarang & 38 & $16.17 \%$ & 37 & $15.74 \%$ \\
\hline & Tidak Pernah & 0 & $0.00 \%$ & 15 & $6.38 \%$ \\
\hline \multirow{3}{*}{$\begin{array}{l}\text { Membayar } \\
\text { Untuk Seks }\end{array}$} & Kadang-Kadang & 0 & $0.00 \%$ & 9 & $3.83 \%$ \\
\hline & Jarang & 5 & $2.13 \%$ & 8 & $0.00 \%$ \\
\hline & Tidak Pernah & 57 & $24.26 \%$ & 156 & $66.38 \%$ \\
\hline
\end{tabular}


Suzy Eka Hazairina, dr : Hubungan Antara Karakteristik Klien LSL dengan Hasil Skrining HIV di UPT Puskesmas X Kota Bandung

\begin{tabular}{lccccc}
\hline Dibayar untuk & Selalu & 1 & $0.43 \%$ & 0 & $0.00 \%$ \\
Seks & Sering & 3 & $1.28 \%$ & 1 & $0.43 \%$ \\
& Kadang-Kadang & 3 & $1.28 \%$ & 17 & $7.23 \%$ \\
& Jarang & 11 & $4.68 \%$ & 12 & $5.11 \%$ \\
& Tidak Pernah & 44 & $18.72 \%$ & 143 & $60.85 \%$ \\
\hline
\end{tabular}

Tabel 3 Karakteristik Klinis Klien LSL di UPT Puskesmas X

\begin{tabular}{|c|c|c|c|c|c|}
\hline Karakteristik & Kategori & HIV $+(n=62)$ & Persentase (\%) & HIV $-(n=173)$ & Persentase (\%) \\
\hline \multirow[t]{2}{*}{ Riwayat IMS } & $\mathrm{Ya}$ & 36 & $15,32 \%$ & 29 & $12,34 \%$ \\
\hline & Tidak & 26 & $11,06 \%$ & 144 & $61,28 \%$ \\
\hline \multirow{2}{*}{$\begin{array}{l}\text { Rasa sakit/panas } \\
\text { saat buang air } \\
\text { kecil disertai } \\
\text { nanah }\end{array}$} & Ya & 18 & $7.66 \%$ & 20 & $8.51 \%$ \\
\hline & Tidak & 44 & $18.72 \%$ & 153 & $65.11 \%$ \\
\hline \multirow{2}{*}{$\begin{array}{l}\text { Keluar nanah } \\
\text { dari anus }\end{array}$} & Ya & 5 & $2.13 \%$ & 3 & $1.28 \%$ \\
\hline & Tidak & 57 & $24.26 \%$ & 170 & $72.34 \%$ \\
\hline \multirow{2}{*}{$\begin{array}{l}\text { Pembengkakan } \\
\text { buah zakar }\end{array}$} & Ya & 26 & $11.06 \%$ & 1 & $0.43 \%$ \\
\hline & Tidak & 36 & $15.32 \%$ & 172 & $73.19 \%$ \\
\hline \multirow{2}{*}{$\begin{array}{l}\text { Pembengkakan } \\
\text { di selangkangan }\end{array}$} & Ya & 22 & $9.36 \%$ & 2 & $0.85 \%$ \\
\hline & Tidak & 40 & $17.02 \%$ & 171 & $72.77 \%$ \\
\hline \multirow{2}{*}{$\begin{array}{l}\text { Perlukaan, } \\
\text { borok, } \\
\text { di kemaluan }\end{array}$} & Ya & 21 & $8.94 \%$ & 9 & $3.83 \%$ \\
\hline & Tidak & 41 & $17.45 \%$ & 164 & $69.79 \%$ \\
\hline \multirow{2}{*}{$\begin{array}{l}\text { Jengger ayam di } \\
\text { anus/ kemaluan }\end{array}$} & Ya & 20 & $8.51 \%$ & 2 & $0.85 \%$ \\
\hline & Tidak & 42 & $17.87 \%$ & 171 & $72.77 \%$ \\
\hline \multirow{2}{*}{$\begin{array}{l}\text { Keluhan } \\
\text { gelembung } \\
\text { berair } \\
\text { bergerombol, } \\
\text { nyeri di sekitar } \\
\text { anus/ kemaluan }\end{array}$} & Ya & 17 & $7.23 \%$ & 0 & $0.00 \%$ \\
\hline & Tidak & 45 & $19.15 \%$ & 173 & $73.62 \%$ \\
\hline
\end{tabular}

Karakteristik klinis diperoleh hanya berdasarkan gejala yang pernah dialami oleh klien LSL, tanpa melakukan pemeriksaan, kecuali klien mempunyai keluhan dan gejala yang bersifat akut atau hasil pemeriksaan sifilis yang dilakukan rutin bersamaan dengan skrining HIV.
Berikut ini disajikan tabel hasil analisis data karakteristik klien LSL dengan hasil skrining HIV, disajikan pada Tabel 4 dibawah ini. 
Tabel 4 Hasil Analisis Data Karakteristik Klien LSL dengan Hasil Skrining HIV

\begin{tabular}{|c|c|c|c|c|c|}
\hline & & HIV (+) & HIV (-) & $\mathbf{X}^{2}$ & P Value \\
\hline \multicolumn{6}{|l|}{$\begin{array}{l}\text { Karakteristik } \\
\text { sosiodemografi }\end{array}$} \\
\hline \multirow{2}{*}{$\begin{array}{l}\text { Pendidikan } \\
\text { Terakhir }\end{array}$} & Dibawah SMA & 2 & 32 & 8,602 & 0.003 \\
\hline & Diatas SMA & 60 & 141 & & \\
\hline \multirow{3}{*}{$\begin{array}{l}\text { Status } \\
\text { Pernikahan }\end{array}$} & Belum Menikah & 57 & 147 & 2,726 & 0.256 \\
\hline & Menikah & 2 & 17 & & \\
\hline & Cerai & 3 & 9 & & \\
\hline \multicolumn{6}{|l|}{$\begin{array}{l}\text { Karakteristik } \\
\text { klinis }\end{array}$} \\
\hline \multirow[t]{2}{*}{ Riwayat IMS } & Ya & 36 & 144 & 38,911 & 0.000 \\
\hline & Tidak & 26 & 29 & & \\
\hline \multicolumn{6}{|l|}{$\begin{array}{l}\text { Karakteristik } \\
\text { seksual }\end{array}$} \\
\hline \multirow{2}{*}{$\begin{array}{l}\text { Jumlah } \\
\text { Pasangan Seks }\end{array}$} & Satu/Tetap & 17 & 68 & 2,793 & 0.095 \\
\hline & Multipartner & 45 & 105 & & \\
\hline \multirow{3}{*}{$\begin{array}{l}\text { Peran Hub. } \\
\text { Seks dengan } \\
\text { Laki-Laki }\end{array}$} & Top & 11 & 92 & 49,836 & 0.000 \\
\hline & Top\&Bottom & 7 & 44 & & \\
\hline & Bottom & 44 & 37 & & \\
\hline \multirow[t]{2}{*}{$\begin{array}{l}\text { Penggunaan } \\
\text { Kondom }\end{array}$} & $\begin{array}{c}\text { Ya } \\
\text { (Selalu/Sering/ } \\
\text { Kadang/Jarang) }\end{array}$ & 62 & 133 & 17,276 & 0.000 \\
\hline & Tidak & 0 & 40 & & \\
\hline \multirow{2}{*}{$\begin{array}{l}\text { Komersialisasi } \\
\text { Seks }\end{array}$} & $\mathrm{Ya}$ & 22 & 43 & 2,577 & 0.108 \\
\hline & Tidak & 40 & 130 & & \\
\hline
\end{tabular}

\section{Pembahasan}

Persentase tertinggi dari tiap karakteristik sosiodemografi klien LSL di UPT Puskesmas X adalah umur diatas 25-49 tahun sebesar 54,89\%, pekerjaan pegawai swasta sebesar $46,8 \%$, pendidikan SMA/setara sebesar $62,1 \%$, domisili di luar wilayah kerja (di dalam kota Bandung) sebesar $66 \%$, dan status belum menikah sebesar $86,8 \%$. Karakteristik ini menjadi dasar penting terkait intervensi program promotif dan preventif yang perlu dilakukan pada klien LSL untuk mencegah penyebaran HIV.

Proporsi tertinggi pada umur diatas 25-49 tahun, hal ini terkait usia aktif seksual. Data nasional penderita HIV/AIDS tertinggi pada kelompok usia 25-49 sebesar 69\%, diikuti kelompok usia 20-24 tahun sebesar $17 \%$. Penelitian di Denpasar menunjukkan bahwa sebanyak 51,2\% LSL merupakan kelompok umur 20-25 tahun. Penelitian di China usia tertinggi 
20-39 tahun sebesar 81,7\%.

Pekerjaan sebagai pegawai swasta menurut penelitian di Denpasar sebesar 73,3 persen. Pendidikan SMA/setara menjadi proporsi tertinggi, juga didapatkan pada penelitian di Denpasar sebesar 64,4\%. Di Jakarta Timur, sebesar $54 \%$, dan di China, tingkat pendidikan tertinggi adalah tingkat akademi/ perguruan tinggi $(61,45 \%){ }^{8,9,10}$ Tingkat pendidikan tertinggi SMA, menjadi dasar untuk melakukan penyuluhan kesehatan reproduksi di kalangan pelajar SMA sebagai bekal dalam memilih dan melakukan aktivitas seksual yang sehat nantinya. Domisili klien LSL di luar wilayah kerja (di dalam kota Bandung) sebanyak $66 \%$ menjadi dasar penting untuk mengembangkan pusat-pusat layanan VCT, khususnya yang ramah komunitas selain UPT Puskesmas X. LSL yang belum menikah sebesar $86,8 \%$, hal ini sebanding dengan penelitian yang ada di Jakarta Timur sebesar 90,2\%, sedangkan di China sebesar $58,45 \%$. Keadaan yang sama juga terjadi di Vietnam dengan angka sebesar $89 \%{ }^{11}$

Pengolahan data umur klien LSL saat seks pertama kali didapatkan usia minimum 11 tahun, usia maksimum 35 tahun dan median usia 20 tahun. Hal ini menjadi penting sebagai dasar sasaran edukasi preventif kelompok usia terkait seks yang sehat dan menghindari penularan HIV/ AIDS.

Pada karakteristik seksual klien LSL UPT Puskesmas X proporsi tertinggi pada pasangan seks pertama kali, berjenis kelamin laki-laki $(70,6 \%)$, pasangan seks sekarang laki-laki sebesar $72,3 \%$, jumlah pasangan seks lebih dari satu (multipartner) sebesar 63,8\%. Peran hubungan seks dengan laki-laki hanya top dan kebanyakan top (insertif) sebesar $43,7 \%$, hal ini sesuai dengan penelitian di Jerman dalam kategori yang sama sebesar 44\%.12 Pemakaian kondom kadangkadang 33,6\% diikuti sering 31,9\%, membayar untuk seks tidak pernah 90,6\%, dibayar untuk seks tidak pernah 79,6\%. Penelitian di Denpasar menunjukkan bahwa berdasarkan pola hubungan seksual, $77,8 \%$ gay memiliki pola hubungan multiple partnership. Penelitian di Jakarta Timur menunjukkan bahwa sebanyak $78,1 \%$ berperilaku seksual tinggi (tidak memakai kondom, berganti-ganti pasangan). Penelitian di Purwokerto menunjukkan bahwa 72\% LSL memiliki partner seks lebih dari satu. ${ }^{13}$ Penelitian di Vietnam selling sex to males sebanyak $44,2 \%$, buying sex from male $50 \%{ }^{14}$

Padakarakteristik klinisklien LSL, persentase tertinggi adalah tidak pernah mengalami gejala IMS sebesar $72,3 \%$, hal ini sesuai dengan penelitian di Cameroon dalam kategori yang sama sebesar $71,29 \% .{ }^{15}$ IMS menjadi salah satu hal penting dalam penularan HIV, dari penelitian ini didapatkan keluhan-keluhan terkait dengan IMS. Berikut adalah 3 keluhan dengan persentase tertinggi yaitu rasa sakit/panas saat buang air kecil disertai nanah sebanyak 38 orang, perlukaan dan borok di kemaluan sebanyak 30 orang, serta jengger ayam di anus/ kemaluan sebanyak 22 orang. Keluhan sakit pada saat buang air kecil disertai nanah biasanya merupakan keluhan yang dialami oleh penderita uretritis gonore maupun non-gonore. Hal ini sebanding dengan hasil penelitian tentang IMS di UPT Puskesmas X tahun 2015 sebanyak 47 kasus, merupakan keluhan IMS terbanyak. ${ }^{16}$ Perlukaan dan borok di kemaluan bisa merupakan keluhan sifilis. Hal ini dapat dibuktikan dengan hasil titer sifilis di laboratorium. Dari hasil keluhan tersering IMS pada klien LSL, penting melakukan intervensi terkait pencegahan dan pengobatan IMS. Jengger ayam di anus/ kemaluan merujuk pada infeksi HPV yang cukup beresiko pada kelompok lain seperti wanita dalam kejadian kanker serviks.

Pengolahan data analisis pengujian korelasi dengan chi-square dilakukan antara karakteristik klien LSL dengan hasil skrining HIV. Dari hasil pengujian didapatkan adanya hubungan pada karakteristik pendidikan terakhir $(\mathrm{p}=0,003)$, riwayat IMS $(p=0,000)$, peran dalam hubungan seks $(p=0,000)$, dan penggunaan kondom $(p=0,000)$ klien LSL dengan hasil skrining HIV. Hal ini merujuk pada hal-hal terkait resiko penularan HIV pada klien LSL di UPT Puskesmas $\mathrm{X}$.

Penelitian ini mempunyai beberapa keterbatasan, yang pertama adalah waktu yang relatif sempit dengan jumlah subjek yang cukup besar menyebabkan peneliti mengalami kesulitan untuk mendapatkan data primer sehingga menggunakan data sekunder yaitu formulir tes dan konseling HIV bagi klien dengan hasil skrining HIV negatif namun hal ini telah dikonfirmasikan ke pendamping (LSM) untuk kelengkapan data subjek. Kedua, subjek penelitian ini merupakan komunitas yang memerlukan pendekatan khusus karena kebutuhan privasi dan kerahasiaan subjek terutama pada klien dengan hasil skrining HIV positif, hal ini menyulitkan peneliti untuk berkomunikasi langsung dengan subjek namun dukungan pendamping (LSM) yang telah diberi pemahaman tentang tata cara pengambilan kuesioner sangat membantu peneliti untuk mendapatkan data subjek.

Penelitian ini diharapkan memiliki dampak penting untuk mengurangi penyebaran dan penularan HIV dikalangan LSL maupun pasangan hetroseksual dengan mengetahui faktor-faktor karakteristik yang mempengaruhi kejadian HIV positif diharapkan dapat menjadi bahan untuk edukasi sebagai tindakan promotif dan preventif 
kepada komunitas tertentu maupun kalangan lainnya.

Simpulan, tingginya angka kunjungan LSL dan hasil skrining HIV positif di UPT Puskesmas $\mathrm{X}$ membutuhkan perhatian khusus untuk mencegah penularan infeksi menular seksual dan HIV dikalangan mereka. Usia reproduksi aktif dengan pendidikan terbanyak setara SMA dan Akademi merupakan tantangan dalam memberi pemahaman tentang pentingnya perilaku seks aman. Hasil analisis pengujian korelasi dengan chi-square, didapatkan adanya hubungan pada karakteristik pendidikan terakhir, riwayat IMS, peran pada seks dan penggunaan kondom dengan hasil skrining HIV. Penggunaan kondom yang konsisten diharapkan menjadi budaya perilaku di kalangan LSL

\section{Daftar Pustaka}

1. Nurulliah N. Kasus HIV-AIDS Jabar Peringkat ke-4 Nasional [Internet]. Pikiran Rakyat. 2016 [cited 24 November 2016]. Available from: http://www.pikiran-rakyat. com/bandung-raya/2016/07/15/kasus-hivaids-jabar-peringkat-ke-4-nasional-374799

2. Mujiati J. Faktor Persepsi Dan Sikap Dalam Pemanfaatan Layanan Voluntary Counseling And Testing (VCT) oleh Kelompok Berisiko HIV/AIDS Di Kota Bandung Tahun 2013. Jurnal Kesehatan Reproduksi. 2014;5(1):48.

3. Kana I, Nayoan C, Limbu R. Perilaku Pencegahan HIV dan AIDS pada Lelaki Suka Lelaki (LSL). Unnes Journal of Public Health. 2016;5(3):252.

4. Noviani A. Duh! 20 -an\% Gay di Surabaya, Bandung, dan Jakarta Kena HIV [Internet]. www.solopos.com. 2016 [cited 24 November 2016]. Available from: http://www.solopos. com/2015/11/30/hivaids-indonesia-duh-20an-gay-di-surabaya-bandung-dan-jakartakena-hiv-665881

5. Maulsby C. Differences and Similarities in HIV Testing Among Men Who Have Sex with Men and Women (MSMW) and Men Who Have Sex with Men Only (MSMO). The Open AIDS Journal. 2012;6:53-59.

6. Lubis K, Jacoeb T, Sirait S. Proporsi Seroprevalensi Imunoglobulin G Virus Herpes Simpleks Tipe 1 Dan 2 pada Laki-Laki yang Berhubungan Seksual Dengan LakiLaki (LSL) yang Terinfeksi HIV dan Tidak Terinfeksi HIV. MDVI. 2013;40(3):108.
7. Mujiati, Sugiharti, Isakh B. Gambaran Pelaksanaan Layanan Voluntary Counseling And Testing (VCT) dan Sarana Prasarana Klinik VCT di Kota Bandung Tahun 2013. Jurnal Kesehatan Reproduksi. 2013;4(3):153.

8. Cempaka P, Kardiwinata M. Pola Hubungan Seksual dan Riwayat IMS pada Gay di Bali. Arc.Com.Health. 2012;1(2):84-89.

9. Chow E, Jing J, Feng Y, Min D, Zhang J, Wilson D, Zhang X, Zhang L. Pattern of HIV Testing and Multiple Sexual Partnerships among Men Who Have Sex with Men in China. BMC Infectious Diseases. 2013;13:549

10. Nugroho A. Perilaku Faktor Harga Diri dan Pusat Pengendalian Diri terhadap Perilaku Seksual Lelaki Seks dengan Lelaki di Jakarta Timur. Jurnal Biotek Medisiana Indonesia. 2012;1(1):21-29.

11. Nguyen H, Nguyen H Q, Colby D. HIV Knowledge and Risks Among Vietnamese Men Who Have Sex With Men Travelling Abroad. International Kournal of STD \& AIDS. 2014;25(9):643-649

12. Marcus U, Ort J, Grenz M, Eckstein K, Wirtz K, Wille A. Risk Factors For HIV and STI Diagnosis in a Community-Based HIV/ STI Testing and Counselling Site for Men Having Sex With Men (MSM) in a Large German City in 2011-2012. BMC Infectious Diseases. 2015;15-14:1-8

13. Laksana A, Lestari D. Faktor-faktor Risiko Penularan HIV/AIDS pada Laki-laki dengan Orientasi Seks Heteroseksual dan Homoseksual di Purwokerto. Mandala of Health. 2010;4(2):116-117.

14. Pham Q, Nguyen T, Nguyen P, Le S, Tran A, Nguyen L, Wilson D, Zhang L. Men Who Have Sex with Men in Southern Vietnam Report High Levels of Substance Use and Sexual Risk Behaviours but Underutilise HIV Testing Services: a Cross-Sectional Study. Sex Transm Infect. 2014;0:1-5

15. Park J, Papworth E, Billong S, Elat J, et al. Correlates of Prior HIV Testing Among Men Who Have Sex with Men in Cameroon: a Cross-Sectional Analysis. BMC Public Health. 2014;14:1220

16. Budiman, Ruhyandi, Pratiwi A. Faktor-faktor yang Berhubungan dengan Kejadian Gonore di Wilayah Kerja Puskesmas Ibrahim Adjie Kota Bandung. 2015:1(1);225-230. 